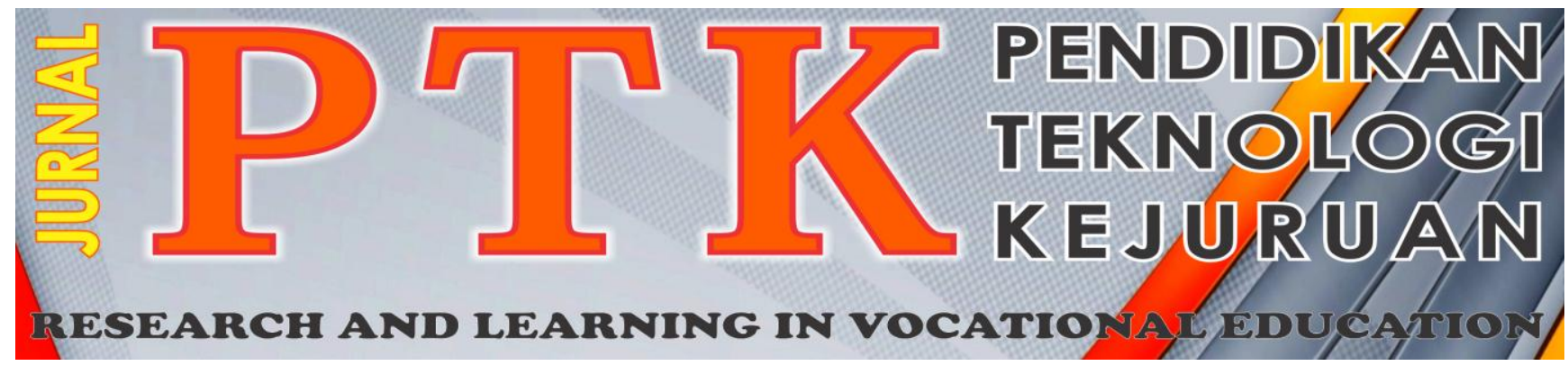

Vol. 1, No. 320118

\title{
EVALUASI PELAKSANAAN KURIKULUM HONDA MENGGUNAKAN MODEL CIPP PADA PAKET KEAHLIAN TEKNIK SEPEDA MOTOR DI SMK NEGERI 1 LAHAT
}

\author{
Aken Derisman $^{1 *}$, Ambiyar ${ }^{2}$, Wakhinuddin ${ }^{2}$ \\ ${ }^{1}$ Akademi Komunitas Kabupaten Lahat \\ ${ }^{2}$ Fakultas Teknik, Universitas Negeri Padang \\ "e-mail: akenderisman@yahoo.com
}

\begin{abstract}
Abstrak- Penelitian ini bertujuan untuk mengevaluasi Pelaksanaan Kurikulum Honda di SMK Negeri 1 Lahat. Jenis penelitian yang digunakan pada penelitian ini adalah penelitian evaluasi dengan model CIPP (Context, Input, Process, Product). Dalam model evaluasi ini terbagi empat tahap yaitu: Context Evaluation, Input Evaluation, Process Evaluation dan Product Evaluation. Pelaksanaan Kurukulum Honda pada Paket Keahlian Teknik Sepeda Motor di SMK Negeri 1 Lahat sudah berada pada kategori baik dengan nilai ratarata TPR $81,00 \%$.
\end{abstract}

\section{Kata Kunci : Evaluasi Pelaksanaan, Pelaksanaan Kurikulum Honda}

Abstract - This study aims to evaluate the Implementation of the Honda Curriculum in SMK Negeri 1 Lahat. The type of research used in this research is evaluation research with CIPP model (Context, Input, Process, and Product). In this evaluation model is divided into four stages: Context Evaluation, Input Evaluation, Process Evaluation and Product Evaluation. The implementation of Honda Curriculum on Motorcycle Engineering Expertise Package at SMK Negeri 1 Lahat is already in good category with average value of $81.00 \%$ TPR.

Keywords : Evaluation of Implementation, Implementation of the Honda Curriculum

\section{PENDAHULUAN}

Kurikulum merupakan acuan dasar dalam pelaksanaan proses pembelajaran. Sekolah memiliki ruang gerak yang luas untuk melakukan modifikasi dan mengembangkan variasi-variasi penyelengaraan pendidikan sesuai dengan keadaan, potensi, kebutuhan, serta kondisi siswa [1][2]. Pendidikan kejuruan merupakan salah satu upaya yang dilakukan untuk menghasilkan tenaga kerja menengah dan berkualitas [3][4]. Namun yang terjadi sebagian besar lulusan Sekolah menengah kejuruan yang belum bisa memenuhi kebutuhan dan tuntutan dari dunia usaha dan dunia industri, Hal ini mengindikasikan bahwa kualitas dari lulusan SMK belum sesuai dengan yang diharapkan, baik dari segi sikap, pengetahuan, dan keterampilan. Untuk itulah pengembangan kurikulum yang relevan dengan kebutuhan masyarakat saat ini mutlak diperlukan [5].
Setiap sekolah mempunyai pedoman yang dinamakan dengan kurikulum. Kurikulum yang digunakan hendaknya dinamis, fleksibel, yakni dapat dirubah sesuai dengan perubahan masyarakat [6] [7]. Sekolah harus mempunyai inovasi dalam menjawab kebutuhan dunia industri. Tujuannya agar lulusan yang dihasilkan oleh SMK sejalan dengan kebutuhan industri.

Inovasi yang dilakukan salah satunya adalah menjalin kerjasama dengan Dunia Industri yaitu Astra Honda Motor dengan bentuk kerja sama "Pengembangan Kurikulum dan Kompetensi SMK Teknik Sepeda Motor Honda di SMK Negeri 1 Lahat". Selanjutnya program kurikulum ini dikenal dengan istilah Kurikulum Honda. Kurikulum bersama atau yang disebut sebagai Kurikulum Honda adalah gabungan dari kurikulum yang disusun oleh SMK N 1 Lahat dengan Kurikulum yang disusun Oleh Pihak honda, kurikulum ini bertujuan untuk 
menyesuikan kebutuhan dari Pihak industri dengan pembelajaran yang ada di sekolah, sehingga kemampuan dari lulusan SMK nantinya bisa sesuai dengan kebutuhan kerja di Dunia Usaha dan Dunia Industri.

Berdasarkan bentuk kerjasama dan keuntungan yang didapat oleh pihak SMK, seharusnya lulusan dari SMK tersebut sudah mempunyai keterampilan sesuai dengan kebutuhan Dunia industri/Dunia industri, sehingga lulusan dari SMK tersebut diharapkan dapat bersaing dan bekerja di Industri khususnya di PT. Astra Honda Motor yang ada diseluruh Indonesia. Tetapi pada kenyataannya Siswa Lulusan dari Teknik Sepeda Motor di SMK N 1 Lahat tidak dapat bersaing di dunia industri dan kesulitan untuk mendapatkan pekerjaan, terutama di PT. Astra Honda Motor.

Berdasarkan permasalah diatas maka penulis tertarik mengambil judul tesis ini "Evaluasi Pelaksanaan Kurikulum Honda Menggunakan Model CIPP pada Paket Keahlian Teknik Sepeda Motor di SMK Negeri 1 lahat. Dengan adanya evaluasi terhadap pelaksanaan kurikulum ini diharapkan menjadi bahan masukan bagi pihak Honda dan sekolah dalam mengambil keputusan apakah program ini dapat dilanjutkan dengan berbagai kekurangan yang terjadi, diperbaiki ataupun program ini dihentikan.

\section{TINJAUAN PUSTAKA}

\subsection{Evaluasi}

Kata Evaluasi yang dalam bahasa inggris dikenal dengan istilah Evaluation. Evaluasi adalah upaya untuk mendokumentasi dan melakukan penilaian tentang apa yang terjadi dan juga mengapa hal itu terjadi, evaluasi yang paling sederhana adalah mengumpulkan informasi tentang keadaan sebelum dan sesudah pelaksanaan suatu program/rencana [8].

Secara umum, pengertian evaluasi adalah suatu proses untuk menyediakan informasi tentang sejauh mana suatu kegiatan tertentu telah dicapai, bagaimana perbedaan pencapaian itu dengan suatu standar tertentu untuk mengetahui apakah ada selisih di antara keduanya, serta bagaimana manfaat yang telah dikerjakan itu bila dibandingkan dengan harapan-harapan yang ingin diperoleh. Evaluasi adalah kegiatan untuk mengumpulkan informasi tentang bekerjanya sesuatu, dan selanjutnya informasi tersebut digunakan untuk menentukan alternatif yang tepat dalam mengambil keputusan [9].

Berdasarkan uraian diatas dapat simpulkan bahwa Evaluasi adalah serangkaian proses kegiatan yang berkenaan dengan mengumpulkan informasi tentang suatu program, yang selanjutnya informasi tersebut digunakan untuk mengukur keberhasilanya dan untuk membuat alternatif - alternatif keputusan, dalam hal ini adalah program kerjasama kurikulum honda antara pihak SMK N 1 Lahat dengan Pihak Honda.

\subsection{Program}

Program adalah segala sesuatu yang coba dilakukan seseorang dengan harapan akan mendatangkan hasil atau pengaruh [10]. Program adalah Suatu unit atau kesatuan kegiatan yang dilakukan bukan hanya satu kali tetapi berkesinambungan [11]. Suatu program mungkin saja sesuatu yang berbentuk nyata (tangible) seperti kurikulum, atau yang abstrak (intangible) seperti prosedur, misalnya distribusi biaya hidup, jadwal lokakarya, atau sederetan kegiatan untuk meningkatkan sikap, dan lain-lain.

Bila akan mengevaluasi suatu program, haruslah secara teratur (sistematik) mengumpulkan informasi tentang bagaimana program itu berjalan, tentang dampak yang mungkin yang terjadi, atau untuk menjawab pertanyaan yang diminati. Kadang-kadang informasi yang dikumpulkan digunakan untuk membuat keputusan tentang program itu misalnya bagaimana memperbaiki program, apakah akan diperluas atau akan dihentikan.

Berdasarkan uraian di atas, dapat disimpulkan bahwa evaluasi program adalah suatu proses pengumpulan data serta penilaian terhadap suatu persoalan untuk memperoleh gambaran, baik dalam bentuk informasi maupun dokumentasi untuk mengetahui tingkat keberhasilan suatu kegiatan yang telah direncanakan dengan langkah-langkah tertentu baik terhadap program yang sedang berjalan maupun program yang telah berlalu yang tujuannya untuk mengambil kebijakan terhadap kegiatan (program) tersebut, seperti menghentikan program, merevisi program, melanjutkan program, dan menyebarluaskan program.

\subsection{Kurikulum}

Kurikulum merupakan program yang tersusun secara terpadu mengenai suatu rencana pendidikan dimana didalamnya menjelaskan mengenai pedoman tentang jenis lingkungan, cara dan proses pendidikan. Selain itu di dalam kurikulum juga berisi mengenai seperangkat rencana peraturan mengenai isi dan bahan pelajaran serta metode apapun model yang digunakan dalam penyelenggarakan kegiatan pembelajaran yang dijadikan pedoman untuk mencapai suatu tujuan tertentu dari pendidikan itu sediri. Curriculum is encompasses the sum of the learning activities and experiences that a student has under the direction of the school" yang bermakna bahwa kurikulum meliputi seluruh kegiatan 
pembelajaran dan pengalaman yang dialami siswa dalam mencapai tujuan sekolah [12].

Kurikulum sendiri memiliki peran yang sangat penting bagi pendidikan karena didalamnya terdapat beberapa pedoman dalam penyelengaraan pendidikan. UU nomor 20 tahun 2003; PP nomor 19 tahun 2005 tentang Sistem Pendidikan Nasional menyatakan Kurikulum sebagai seperangkat rencana dan peraturan mengenai tujuan, isi dan bahan pelajaran serta cara yang digunakan sebagai pedoman penyelenggaraan pembelajaran untuk mencapai tujuan pendidikan tertentu.

Berdasarkan uraian diatas dapat disimpulkan bahwa Kurikulum adalah seperangkat mata pelajaran dan program pendidikan yang diberikan oleh suatu lembaga penyelenggara pendidikan yang berisi rancangan pelajaran yang akan diberikan kepada peserta pelajaran dalam satu periode jenjang pendidikan. Penyusunan perangkat mata pelajaran ini disesuaikan dengan keadaan dan kemampuan setiap jenjang pendidikan dalam penyelenggaraan pendidikan tersebut serta kebutuhan lapangan kerja.

\subsection{Kurikulum Honda}

Kurikulum bersama atau yang disebut sebagai Kurikulum Honda adalah gabungan dari kurikulum yang disusun oleh SMK N 1 Lahat dengan Kurikulum yang disusun Oleh Pihak Astra Honda Motor (AHM), kurikulum ini bertujuan untuk menyesuaikan kebutuhan dari Pihak industri dengan pembelajaran yang ada di sekolah, sehingga kemampuan dari lulusan SMK nantinya bisa sesuai dengan kebutuhan kerja di Dunia Usaha dan Dunia Industri.

Pada kurikulum yang direncanakan dan dibuat oleh sekolah dan pihak Honda ini prinsipnya tidak jauh berbeda dengan acuan dan patokan dari kurikulum KTSP 2006. Beberapa hal yang membedakannya adalah pada kurikulum yang dikembangkan ini lebih menekankan pada aspek pelaksanaan pembelajarannya, yakni porsi untuk belajar praktikum lebih di prioritaskan dari pada aspek teoritis, pada pembelajaran teoritis sebanyak $30 \%$ dan pembelajaran praktikum $70 \%$, sehingga nantinya pembelajaran lebih banyak melakukan praktikum.

Orientasi pembelajaran lebih banyak melakukan praktikum, pihak Honda memberikan sejumlah bantuan materil yakni bantuan peralatan berupa Special Servive Tools (SST), buku manual service lengkap untuk semua jenis sepeda motor Honda, memberikan satu unit sepeda motor, dan mengadakan training bagi guru Jurusan Teknik Sepeda Motor. Adapun program Kurikulum Honda ini sebagai berikut:
1) Mengadakan pelatihan/training bagi guru SMK khususnya guru Jurusan Teknik Sepeda Motor SMK Negeri 1 Lahat.

2) Melakukan seleksi perekrutan tenaga mekanik dari lulusan SMK Negeri 1 Lahat.

3) Prakerin dilakukan pada bengkel resmi sepeda motor Honda

4) Bagi para lulusan akan diberikan sertifikat kompetensi dari PT. Astra Honda Motor, tbk.

5) Memberikan bantuan peralatan praktikum berupa satu unit sepeda motor, buku pedoman reparasi sepeda motor Honda, dan kunci-kunci khusus.

\subsection{Evaluasi Program Kurikulum Honda Menggunakan Model CIPP}

Model evaluasi adalah suatu model desain evaluasi yang dibuat oleh ahli-ahli atau pakar-pakar evaluasi yang biasanya dinamakan sama dengan pembuatnya atau tahap pembuatannya [10]. Model evaluasi CIPP mulai dikembangkan oleh Daniel Stufflebeam pada tahun 1966. Stufflebeam mendefinisikan evaluasi sebagai proses melukiskan (delineating), memperoleh (obtaining), dan menyediakan (providing) informasi yang beguna (useful information) untuk menilai alternatifalternatif pembuatan keputusan. Melukiskan artinya menspesifikasi, mendefinisikan dan menjelaskan unutk menfokuskan informasi yang diperlukan untuk mengambil keputusan. Memperoleh artinya dengan memakai pengukuran dan statistik unutk mengumpulkan, mengorganisir dan menganalisis informasi. Menyediakan artinya mensistensikan informasi sehingga akan melayani dengan baik kebutuhan evaluasi para pemangku kepentingan evaluasi.

Mmodel CIPP adalah model evaluasi yang memandang program yang dievaluasi sebagai sebuah sistem. Kebanyakan model yang dipakai saat ini adalah CIPP (Context, Input, Process, Product), karena pada umumnya suatu program yang dikembangkan berdasarkan sistem, sehingga alur pikiran kerutunan sistem membuat model CIPP lebih layak dipakai dalam mengevaluasi suatu program [13].

Model CIPP terdiri dari emat jenis evaluasi yaitu: Evaluasi Konteks (context evaluation), Evaluasi Masukan (input evaluation), Evaluasi Proses (process evaluation) dan Evaluasi Produk (product evaluation), yang mana terdiri dari:

a. Evaluasi Konteks (Context evaluation). Menurut Daniel Stufflebeam evaluasi konteks untuk menjawab pertanyaan: Apa yang diperlukan? (What needs to be done?) evaluasi ini mengidentifikasi dan menilai kebutuhan-kebutuhan yang mendasari disusunnya suatu program. 
b. Evaluasi Masukan. Evaluasi masukan untuk mencari jawaban atas pertanyaan: apa yang harus dilakukan? (What sould be done?) evaluasi ini mengidentifikasi masalah, aset dan peluang untuk membantu para pengambil keputusan mendefinisikan tujuan, prioritas-prioritas dan membantu kelompokkelompok lebih luas pemakai untuk menilai tujuan, prioritas, dan manfaat-manfaat dari program, menilai pendekatan alternatif, rencana tindakan, rencana staf, dan anggaran untuk feasibilitas dan potensi cost effectiveness untuk memenuhi kebutuhan dan tujuan yang ditargetkan. Para pengambil keputusan memakai evaluasi masukan dalam memilih diantara rencana-rencana yang ada, menyusun proposal pendanaan, alokasi sumber-sumber, penempatan staf, menscedul pekerjaan, menilai rencana-rencana aktivitas dan penganggaran.

c. Evaluasi Proses. Evaluasi proses berupaya untuk mencari jawaban atas pertanyaan: apakah program sedang dilaksanakan? (is it being done?) evauasi ini berupaya mengakses pelaksanaan dari rencana membantu staf program melaksanakan aktivitas dan kemudian membantu kelompok pemakai yang lebih luas menilai program dan menginterprestasikan manfaat.

d. Evaluasi produk. Evaluasi produk diarahkan untuk mencari jawaban pertanyaan: did ti succed? Evaluasi ini berupaya mengidentifikasi dan mengakses keluaran dan manfaat, baik yang direncanakan atau tidak direncanakan, baik jangka pendek maupun jangka panjang. Keduanya untuk mambantu staf menjaga upaya memfokuskan pada mencapai manfaat yang penting dan akhirnya untuk membantu kelompok-kelompok pemakai lebih luas mengukur kesuksesan upaya dalam mencapai kebutuhan-kebutuhan yang ditargetkan.

\section{METODE}

Jenis penelitian yang digunakan pada penelitian ini adalah penelitian evaluasi dengan model CIPP (Context, Input, Process, Product). Model CIPP memandang program tersebut yang dievaluasi sebagai sebuah sistem, oleh karena itu program tersebut dianalisis berdasarkan komponen kontek, masukan, proses, dan hasil. Model evaluasi ini terbagi menjadi empat tahap yaitu: Context Evaluation, Input Evaluation, Process Evaluation dan Product Evaluation.

Metode penelitian yang digunakan adalah metode kombinasi (Mixed Method Research).Metode penelitian kombinasi (mixed methods) adalah suatu metode penelitian yang mengkombinasikan atau menggabungkan antara metode kuantitatif dan metode kualitatif untuk digunakan secara bersamasama dalam suatu kegiatan penelitian sehingga diperoleh data yang lebih komprehensif, valid, reliabel dan objektif [14].

Model penelitian yang digunakan pada metoda ini adalah model Concurent Triangulaiton, Concuurent Triangulation adalah metoda penelitian yang menggabungkan antara metoda penelitian kualitatif dan kuantitatif secara berimbang. Metode ini digunakan secara bersama-sama, dalam waktu yang sama, tetapi independen untuk menjawab rumusan masalah yang sejenis [14].

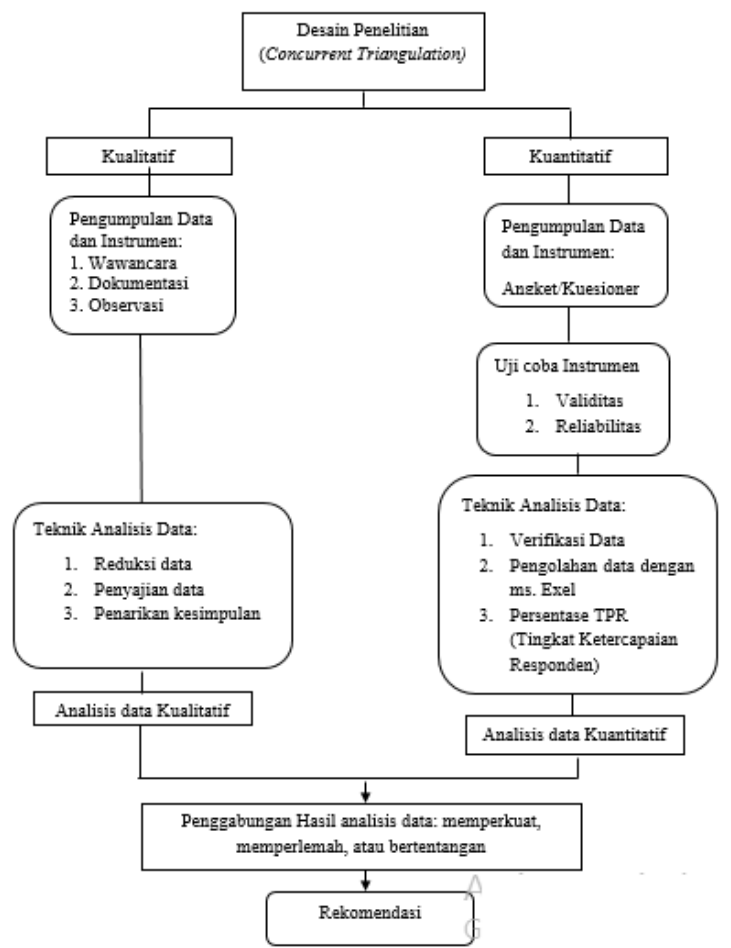

Gambar 3.1 Diagram Alir Penelitian

\subsection{Objek Evaluasi dan Responden}

\section{Objek Evaluasi}

Objek penelitian ini adalah lingkungan (kebutuhan, peluang, aset, dan masalah), guru (kualifikasi dan kompetensi), siswa (minat dan motivasi), sarana dan prasarana, aktivitas guru, aktivitas siswa, hasil belajar, potensi yang dimiliki, kecakapan, bakat, sikap dan tingkat penguasaan siswa Paket Keahlian Teknik Sepeda Motor kelas XII SMK Negeri 1 Lahat Tahun Ajaran 2017/2018) Tabel 3.2 Hasil Validasi Perangkat. 
2. Responden

Tabel 1. Responden Penelitian

\begin{tabular}{|c|c|c|c|c|c|}
\hline \multicolumn{6}{|c|}{ Sumber Data Penelitian } \\
\hline \multicolumn{3}{|c|}{ Pendekatan kuantitatif } & \multicolumn{3}{|c|}{ Pendekatan Kualitatif } \\
\hline No & Responden & Jumlah & No & Responden & Jumlah \\
\hline 1 & $\begin{array}{l}\text { Siswa Kelas } \\
\text { XII TSM TA } \\
2017 / 2018\end{array}$ & 28 Orang & $\begin{array}{l}1 \\
2 \\
3 \\
4 \\
5 \\
\\
6 \\
7\end{array}$ & $\begin{array}{l}\text { Pihak Honda } \\
\text { Kepala Sekolah } \\
\text { Waka Kurikulum } \\
\text { Waka Humas } \\
\text { Kepala Program } \\
\text { Keahlian teknik } \\
\text { otomotif } \\
\text { Guru produktif } \\
\text { TSM } \\
\text { Peserta didik }\end{array}$ & $\begin{array}{l}1 \\
1 \\
1 \\
1 \\
1\end{array}$ \\
\hline \multicolumn{2}{|r|}{ Jumlah } & 28 Orang & \multicolumn{2}{|r|}{ Jumlah } & 9 Orang \\
\hline \multicolumn{3}{|c|}{$\begin{array}{c}\text { TOTAL } \\
\text { RESPONDEN }\end{array}$} & \multicolumn{3}{|c|}{37 Orang } \\
\hline
\end{tabular}

\subsection{Uji Coba Instrument}

1. Uji Validitas

Uji validitas angket ditentukan dengan menggunakan rumus Product Moment [8].

$$
\begin{aligned}
& \begin{array}{l}
r=\frac{n \sum X Y-\left(\sum X\right)}{\sqrt{\left\{n \sum X^{2}-\left(\sum X\right)^{2}\right\}\left\{n \sum Y^{2}\right.}} \\
\text { dimana: } \\
\mathrm{r}=\text { koefisien korelasi } \\
\sum X=\text { jumlah skor } \mathrm{X}
\end{array} \\
& \sum Y=\text { jumlah skor } \mathrm{y} \\
& \mathrm{n}=\text { jumlah responden }
\end{aligned}
$$

\begin{tabular}{|c|c|c|c|c|c|}
\hline Evaluasi & Indikator & $\begin{array}{l}\text { Total } \\
\text { Item }\end{array}$ & $\begin{array}{l}\text { Jumlah } \\
\text { Gugur }\end{array}$ & $\begin{array}{c}\text { No Butir } \\
\text { Gugur }\end{array}$ & $\begin{array}{c}\text { Jumlah } \\
\text { Valid }\end{array}$ \\
\hline \multirow[t]{4}{*}{ Context } & 1. Kebutuhan & 2 & 0 & - & 2 \\
\hline & 2. Peluang & 2 & 0 & - & 2 \\
\hline & 3. Aset & 5 & 1 & 5 & 4 \\
\hline & 4. Masalah & 6 & 0 & - & 6 \\
\hline \multirow[t]{3}{*}{ Input } & 1. Guru & 10 & 3 & $19,22,24$ & 7 \\
\hline & 2. Peserta didik & 6 & 0 & - & 6 \\
\hline & $\begin{array}{l}\text { 3. Sarana } \\
\text { Prasarana }\end{array}$ & 6 & 0 & - & 6 \\
\hline \multirow[t]{3}{*}{ Process } & $\begin{array}{l}\text { 1. Pelaksanaan } \\
\text { pembelajaran }\end{array}$ & 3 & 0 & - & 3 \\
\hline & $\begin{array}{l}\text { 2. Aktivitas } \\
\text { Guru }\end{array}$ & 7 & 2 & 43,45 & 5 \\
\hline & $\begin{array}{l}\text { 3. Aktivitas } \\
\text { Siswa }\end{array}$ & 7 & 2 & 50,54 & 5 \\
\hline \multirow[t]{4}{*}{ Produk } & $\begin{array}{l}\text { 1. Kemajuan } \\
\text { hasil belajar }\end{array}$ & 2 & 0 & - & 2 \\
\hline & $\begin{array}{l}\text { 2. Potensi Yang } \\
\text { dimiliki }\end{array}$ & 3 & 0 & - & 3 \\
\hline & $\begin{array}{l}\text { 3. Kecakapan, } \\
\text { bakat dan } \\
\text { sikap }\end{array}$ & 7 & 2 & 63,66 & 5 \\
\hline & $\begin{array}{l}\text { 4. Tingkat } \\
\text { Penguasaan }\end{array}$ & 2 & 0 & - & 2 \\
\hline \multicolumn{2}{|c|}{ Jumlah } & 68 & 10 & - & 58 \\
\hline
\end{tabular}

Tabel 2. Analisa Validitas Instrument

\section{Reliabilitas}

Untuk menguji reliabilitas instrumen digunakan rumus Alpha [8]

$$
r_{11}=\frac{k}{k-1}\left(1-\frac{\sum S_{i}}{S t}\right)
$$

Berdasarkan pengujian reliabilitas menggunakan program MS.Exel diketahui nilai koefsiensi untuk keseluruhan indikator reliabilitas instrument sebesar 0,973 dengan kategori sangat tinggi.

\subsection{Teknik Pengumpulan Data}

\section{Data Kauntitatif}

Teknik pengumpulan data kuantitatif yang digunakan dalam penelitian ini adalah dengan kusioner (angket). Pada penelitian ini menggunakan angket tertutup, dimana komunikasi dilakukan dengan cara tidak langsung. Angket tertutup menurut Riduwan [13]. Angket yang disajikan dalam bentuk sedemikian rupa sehingga responden diminta memilih satu jawaban yang sesuai dengan karakteristik dirinya dengan cara memberikan tanda silang (x) atau tanda checklist (v).

\section{Data Kualitatif}

Dalam penelitian kualitatif, menurut Sugiyono [15] "pengumpulan datanya dilakukan pada natural setting (kondisi yang alamiah), sumber data primer, dan teknik pengumpulan data pada observasi berperan serta, wawancara mendalam dan dokumentasi". Oleh karena itu dalam penelitian ini untuk mendapatkan data yang bersifat kualitatif maka peneliti akan menggunakan observasi, wawancara dan dokumentasi.

\subsection{Teknik Analisa Data}

\section{Data Kualitatif}

Analisis data kualitatif dalam penelitian ini menggunakan model Miles dan Huberman dalam Sugiyono [15] dapat dilakukan dengan langkah - langkah sebagai berikut:
a. Reduksi data
b. Display data
c. Verifikasi data

\section{Data Kuantitatif}

Analisis data Kuantitatif dilakukan dengan prosedur dan tahapan sebagai berikut: 1) melakukan pentabulasian data terhadap angket penelitian yang telah diisi oleh responden. 2) melakukan perhitungan setiap indikator. 3) menghitung skor total. 4) menganalisis dengan analisis persentase. Untuk mendiskripsikan data yang telah diperoleh dilakukan dengan tujuan melihat kecendrungan distribusi frekuensi dan menentukan Tingkat Pencapaian Responden (TPR) pada masing-masing variabel dan indikator menggunakan rumus Riduwan [16]. TPR akan diketahui dengan rumus sebagai berikut: 
$\mathrm{TPR}=\frac{\text { skor rata-rata }}{\text { jumlah item } \mathrm{x} \text { jumlah responden } \mathrm{x} \text { skor ideal maksimum }} \mathrm{X} 100 \%$

Pengkategorian nilai TPR digunakan kalasifikasi yang di kemukakan Syahron Lubis [17] seperti pada tabel berikut:

Tabel 3. Rentang Kategori TPR

\begin{tabular}{|c|c|}
\hline Rentang Persentase & Kategori \\
\hline $90 \%-100 \%$ & Sangat Baik \\
\hline $80 \%-89 \%$ & Baik \\
\hline $65 \%-79 \%$ & Cukup \\
\hline $55 \%-64 \%$ & Kurang \\
\hline $0 \%-54 \%$ & Kurang Sekali \\
\hline
\end{tabular}

\section{HASIL DAN PEMBAHASAN}

\subsection{Hasil Penelitian}

1. Komponen Konteks

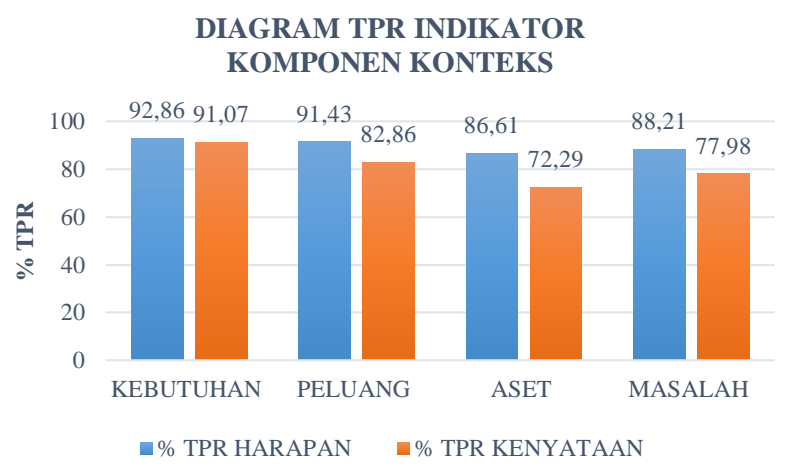

Gambar 1. Diagram TPR Komponen Konteks

a. Kebutuhan Program

Indikator kebutuhan TPR 91,07\% termasuk kategori sangat baik. Kebutuhan pada program ini sudah terpenuhi, dilihat dari: guru yang berkompeten, siswa TSM, Mekanik yang handal, Kurikulum bersama, dan fasilitas bengkel standar astra motor honda.

b. Peluang yang dimiliki

Indikator peluang TPR $82,86 \%$ termasuk kategori baik. Sekolah sudah memberikan peluang kepada siswa dalam memilih sendiri tempat prakerin, dan peluang dalam meningkatkan kompetensinya. Sedangkan peluang yang diberikan pihak honda adalah mendapatkan kesempatan bekerja bagi siswa yang memiliki kompetensi.

c. Aset yang dimiliki

Indikator aset TPR 72,29\% termasuk kategori cukup. Hal yang perlu diperbaiki : Pelayanan Toolman, kurangnya kegiatan yang diadakan oleh sekolah. d. Masalah yang ditemui

Indikator masalah yang ditemui TPR 77,98\% termasuk kategori cukup .

Adapun Masalah yang ditemui di indikator masalah ini pada lingkungan sekolah dan lingkungan kerja.

\section{Komponen Masukan}

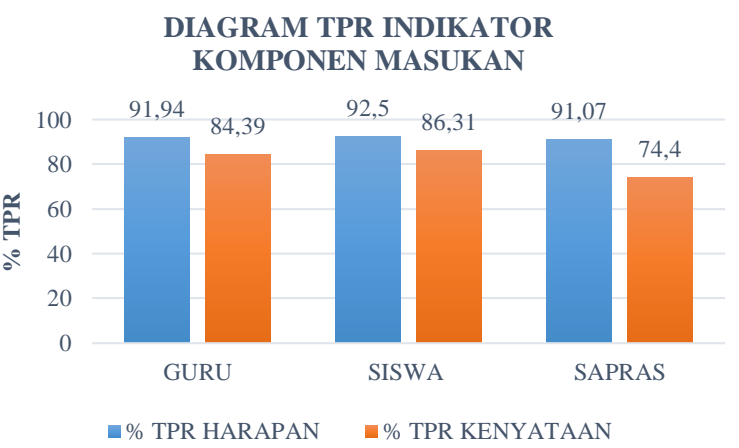

Gambar 2. Diagram TPR Komponen Masukan

a. SDM Guru (kualifikasi dan kompetensi)

Indikator Guru rata-rata TPR 84,39 termasuk kategori Baik. Guru produktif TSM sudah sesuai kualifikasi, kompetensi guru juga sudah baik, dilihat dari guru sering mengiukuti pelatihan dari pihak honda, sedangkan jumlah produktif TSM masih kurang.

b. SDM Siswa (minat dan motivasi)

Indikator SDM Siswa rata-rata TPR 86,31\% pada kategori Baik. Minat siswa baik dan motivasi siswa juga cukup tinggi.

c. Sarana dan Prasarana Indikator Sapras rata-rata TPR $74,4 \%$ pada kategori Cukup. Hal - hal yang perlu di perbaiki adalah: Peralatan praktek yang belum lengkap, Bahan praktek juga kurang lengkap, dan Ruangan praktek yang belum memadai.

\section{Komponen Proses}

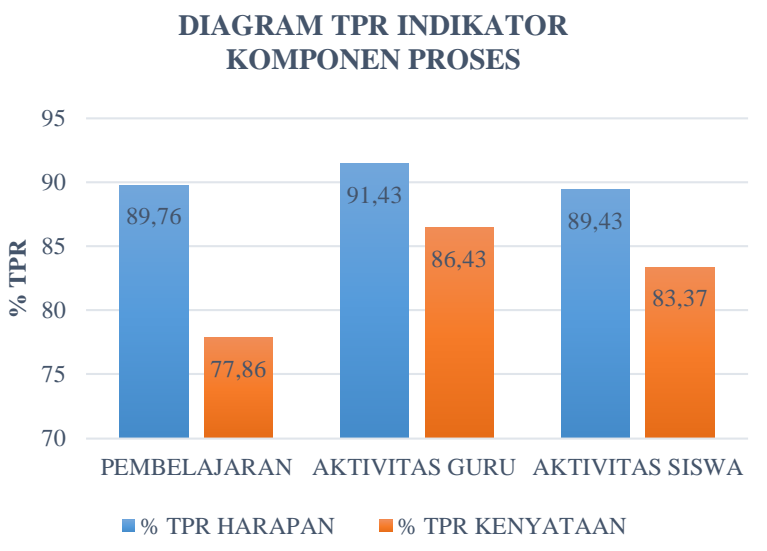

Gambar 3. Diagram TPR Komponen Proses 
a. Pelaksanaan Pembelajaran

Indikator pelaksanaan pembelajaran rata-rata TPR 77,86\% termasuk kategori cukup. Adapun permasalahan pada pelaksanaan pembelajaran ini adalah : kurangnya Pengawasan saat pratikum dan Waktu prakerin siswa yang singkat.

b. Aktivitas Guru

Indikator aktivitas guru rata-rata TPR $86,43 \%$ termasuk kategori Baik. Guru menyampaikan tujuan pembelajaran kepada siswa, Guru mencontohkan terlebih dahulu pekerjaan sebelum siswanya, dan guru memberikan joobseet kepada siswa sebagai pedoman praktek.

c. Aktivitas Siswa

Indikator aktivitas siswa rata-rata TPR $83,37 \%$ termasuk kategori Baik. Siswa menganalisa sendiri kerusakan pada sepeda motor, siswa mengikuti joobseet saat praktek, siswa cukup aktif saat belajar.

\section{Komponen Produk}

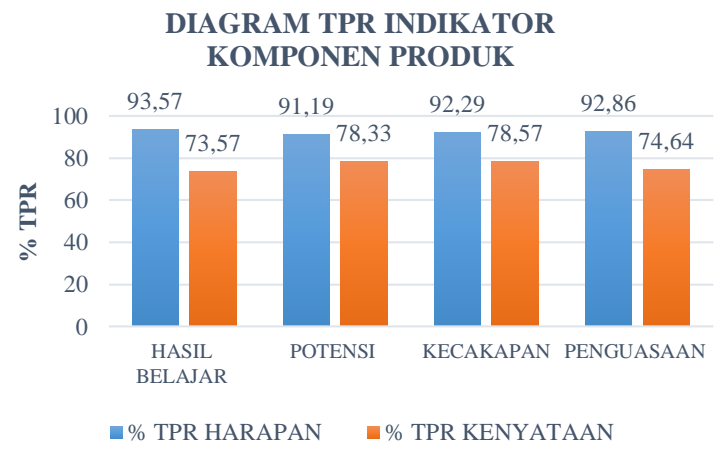

Gambar 4. Diagram TPR Komponen Produk

a. Peningkatan Hasil Belajar

Indikatior hasil belajar rata-rata TPR 73,57\% termasuk kategori Cukup. Tidak semua siswa nilainya meningkat tiap semester, ada juga yang tidak lulus KKM dan melakukan remedial.

b. Potensi yang dimiliki

Indikatior Potensi yang dimilik rata-rata TPR 78,33\% termasuk kategori Cukup. hasil belajar (kemampuan praktek) siswa belum bisa dimanfaatkan oleh lingkungan sekitar.

c. kecakapan, bakat dan sikap.

Indikatior ini rata-rata TPR $78,57 \%$ termasuk kategori Cukup. sebagian siswa belum bisa menyelesaikan pekerjaan sendiri, bakat yang dimiliki belum terlihat saat melaksanakan prakerin dan sikap siswa sudah cukup baik.

d. Tingkat Penguasaan

Indikatior tingkat penguasaan ini rata- rata TPR 74,64\% termasuk kategori Cukup. siswa belum mampu menerapkan ilmu yang di dapat disekolah saat prakerin, dan sebagian siswa belum bisa bekerja sesuai SOP.

\subsection{Pembahasan}

Dari hasil penelitian yang dilakukan di SMK Negeri 1 Lahat tentang Pelaksanaan Program Kerjasama Kurikulum Honda dilihat dari Contexs, Input, Prosess dan Product. Secara keseluruhan rata-rata hasil evaluasi Pelaksanaan Kurikulum Honda adalah sebesar 81,00\% artinya berada pada kategori baik.

Tetapi untuk mendapatkan hasil yang optimal masih perlu ada perbaikan lagi pada bagian indikator yang termasuk dalam kategori kurang atau cukup, seperti indikator: Aset yang dimiliki, Masalah Lingkungan, SDM Guru, Sarana Prasarana, Pelaksanaan Pembelajaran, Aktivitas Guru, Peningkatan hasil belajar, Potensi yang dimiliki, Kecakapan dan Tingkat Penguasaan.

\section{KESIMPULAN}

Mengacu pada Rumusan masalah serta berdasarkan analisis dan pembahasan, maka Evaluasi pelaksanaan kurikulum Honda menggunakan Model CIPP dapat ditarik kesimpulan sebagai berikut:

1. Pelaksanaan Kurikulum Honda di SMK Negeri 1 Lahat pada komponen Konteks sudah berada pada kategori baik dengan nilai rata-rata TPR $82,80 \%$.

2. Pelaksanaan Kurikulum Honda di SMK Negeri 1 Lahat pada komponen Masukan sudah berada pada kategori baik dengan nilai rata-rata TPR $81,70 \%$.

3. Berdasarkan hasil penelitian dan pembahasan dapat disimpulkan bahwa komponen proses pada penelitian ini sudah tergolong baik dengan nilai rata-rata TPR $82,62 \%$.

4. Berdasarkan hasil penelitian dan pembahasan dapat disimpulkan bahwa komponen Product pada penelitian ini tergolong pada kategori cukup dengan nilai rata-rata TPR 76,28\%.

Berdasarkan penjelasan diatas secara keseluruhan dapat disimpulkan bahwa Pelaksanaan Kurukulum Honda pada Paket Keahlian Teknik Sepeda Motor di SMK Negeri 1 Lahat sudah berada pada kategori Baik, dan tiap komponen evaluasinya sudah mendukung terlakasananya program kurikulum honda ini, tetapi untuk mendapatkan hasil yang optimal masih perlu ada perbaikan lagi pada bagian indikator yang termasuk dalam kategori kurang atau cukup 


\section{DAFTAR PUSTAKA}

[1] D. Pernanda, M. A. Zaus, R. E. Wulansari, and S. Islami, "Effectiveness of instructional media based on interactive cd learning on basic network at vocational high school: improving student cognitive ability," Int. Conf. Educ. Soc. Sci. Technol., no. January, pp. 440-444, 2018.

[2] M. A. Zaus, R. E. Wulansari, S. Islami, and D. Pernanda, "Perancangan Media Pembelajaran Listrik Statis dan Dinamis Berbasis Android," vol. 1, no. 1, pp. 1-7, 2018.

[3] R. E. Wulansari, D. Puyada, I. Wijaya, and K. Rukun, "EFFECTIVENESS OF INSTRUCTIONAL MEDIA BASED GAME ON MATHEMATICS AT VOCATIONAL HIGH SCHOOL," Int. J. Res. Sci. Manag., vol. 4, no. 12, pp. 125-128, 2017.

[4] N. Jalinus, Syahril, and R. A. Nabawi, "Effectivity of The Cooperative-Project Based Learning ( CPjBL ) in Enhancing HOTS of Vocational Education Students," no. 1, pp. 83-86, 2018.

[5] S. Sukardi, D. Puyada, R. E. Wulansari, and D. T. P. Yanto, "The validity of interactive instructional media on electrical circuits at vocational high school and technology," in the 2nd INCOTEPD, 2017, vol. 2017, no. October, pp. 21-22.

[6] M. A. Zaus, "Suatu Kajian Literatur MasalahMasalah yang Dihadapi dalam Mata Kuliah Jaringan Komputer," vol. 18, no. 1, pp. 1-8, 2018.

[7] R. Lapisa, I. Y. Basri, A. Arif, and H. D. Saputra, "PENINGKATAN KOMPETENSI SISWA MELALUI PELATIHAN AUTO CAD," vol. 17, no. 2, 2017.

[8] Stufflebeam, Daniel L. \& Shinkfield, Antony J. Evaluation Theory, Models, and Application, San Fransisco: Jossey-Bass. 2007.

[9] Suharsimi Arikunto. Dasar-Dasar Evaluasi Pendidikan. Jakarta: Bumi Aksara. 2004.

[10] Farida Yusuf Tayibnapis. Evaluasi Program dan Instrumen Evaluasi. Jakarta: Rineka Cipta. 2008.
[11] Suharsimi Arikunto \& Cepi Safruddin Abdul Jabar. Evaluasi Program Pendidikan. Jakarta: Bumi Aksara. 2010.

[12] Finch \& Crunkilton. Review and Critique of strategies for determining career education curriculum content. San fransisco. 1979.

[13] Wakhinunddin S. Evaluasi Program. Padang: UNP Press. 2008

[14] Sugioyono. Metode Penelitian Kombinasi. Alfabeta: Bandung. 2016.

[15] Sugiyono. Metode Penelitian Pendidikan Pendekatan Kuantitatif, Kualitatif, dan $R \& D$. Alfabeta: Bandung. 2014.

[16] Riduwan. Dasar-dasar Statistika. Bandung: Alfabeta. 2009.

[17] Syahron Lubis. Metodologi Penelitian Pendidikan Padang: Sukabina Press. 2011.

\section{Biodata Penulis}

Aken Derisman, Lahir di Tanjung Pinang, 05 Desember 1990. Sarjana Pendidikan di Jurusan Teknik Otomotif Universitas Negeri Padang tahun 2013. Staf pengajar di jurusan Teknik Alat Berat Akademi Komunitas Kabupaten Lahat sejak tahun 2015 sampai sekarang.

Ambiyar, Lahir di Padang Panjang, 13 Februari 1955. Staf pengajar di jurusan Teknik Mesin FT UNP dan staf pengajar di Program Pascasarjana FT UNP.

Wakhinuddin Simatupang, Lahir di Sibolga, 14 Maret 1985. Sarjana Pendidikan lulusan IKIP Padang, Magister Pendidikan lulusan IKIP Yogyakarta dan Doktor lulusan UNJ Jakarta. Star pengajar di jurusan Teknik Otomotif FT UNP dan staf pengajar di Program Pascasarjana FT UNP. 